\title{
Welcoming the Stranger: Responding to the Global Refugee
}

\section{Crisis}

\section{Daniel W. O’Neill ${ }^{\mathrm{a}}$}

\author{
${ }^{a} \mathrm{MD}, \mathrm{MA}(\mathrm{Th})$, Managing Editor
}

With 68.5 million people forcibly displaced worldwide, and 25.4 million refugees, there is a global need that is unprecedented in scale. ${ }^{1} 85 \%$ of the world's displaced reside in developing countries, and the global church is faced with how to respond to this crisis. What does our Lord require in response to this reality?

I addressed this question at an inter-faith roundtable discussion at a conference at Princeton University March 3-5, 2017 called Seeking Refuge: Faith Based Approaches to Forced Migration. ${ }^{2}$ From a Christian perspective, I shared that all people are made in the image of God and deserve respect. Abraham was blessed to be a blessing to all nations. Foreigners (ger) were included under the same laws in the Torah because of God's love for them and the call to love our neighbor (Lev 19:18). The Messiah reaffirmed this as the sum of the law and the prophets (Lk 10:27). One of the purposes of the Shabbat was to refresh the foreigner living among the people of God. Israel was considered a foreigner even in their own land and historically were refugees from Egypt, which created solidarity with the displaced. "You and the foreigner will be the same before the Lord," with equality and unity in worship (Num 15:13-16). Inclusiveness is written into the structure of the temple, and John's eschatological vision of the inclusive society included all peoples (Rev7:9). "The leaves from the tree of life are for the healing of the nations." (Rev 22:2)

YHWH directed the establishment of six Levitical cities of refuge in Palestine which showed

Sept 2018. Christian Journal for Global Health, 5(2):1-2.

a pattern of trans-cultural permanency in God's intention for humanity (Num 35:6-29). These cities were safe havens for Jews and foreigners, and each carried significant Hebrew names ("set apart", "to carry a burden", "fellowship/collaborative", "protected", "lifted up", and "enfolding joy"), expressing the heart of God and the call to his people. These accessible cities allowed refugees to be assessed, then incorporated/protected from blood vengeance cycles, with the goal of repatriation. In the Torah, justice, provision and a portion of the tithe were intended for the "fatherless, the foreigner and the widow" - specifying the most vulnerable. The law's moral imperative was reiterated and read publicly. The prophets expounded social justice to the foreigner and spoke judgment against those who mistreat the foreigner.

Jesus, once a child refugee, identified himself with the foreigner, the oppressed - "If you support them, you're supporting me" (Mat 25). God himself is a refuge for the oppressed (Ps 9:9), and the covenant community can become a refuge for others. Paul calls for the practice of hospitality (philoxenia) "love to the stranger" in contrast to xenophobia. We (as well as the prophets) are sojourners, in solidarity with refugees, as we long for a permanent dwelling (Phil 3:20). Perfect love drives out fear, and is the moral imperative of Christ followers (1 John 4:8). Though there is an existing disconnect between belief and practice, fear and over- commitment to safety, and conflation of political loyalty with the gospel; there is emerging interdenominational commitment - a call 
to return to the character of God, the words of the prophets, unity and to the supreme example of the Messiah toward the stranger.

Given the body of biblical support, in both the old and the new covenants, it is surprising that attitudes towards refugees in the Christian community can at times be ambivalent, or at worst xenophobic. How can Christian educators, leaders and practitioners justly and effectively respond to the challenge of displaced populations following the way of Jesus?

In this issue, we present several perspectives and approaches to responding to the current global refugee crisis. Professor Boan and colleagues present a novel distributive justice approach from a network of churches which address conflict in the Kakuma refugee camp in Kenya. Costello and von Kalm offer a commentary on the approach Christians should take in response to asylum seekers on the shores of Australia, which can be applied in many other geo-political contexts. Suleiman, et. al. present a case report which analyzes a church-based health home care model which was applied in Jordan among Syrian and Iraqi refugees. Agner presents an inspiring field story of his experience in Central Europe along the stream of Syrian refugee migrations.
In addition, we offer reports from the annual meeting of the Consortium of Universities of Global Health, focusing on refugee care, climate change, a global health debate, gender and economic disparities, research and publication. We hope this overview gives a glimpse of some of the global health issues we are facing and which demands a faith-inspired and articulate response.

In the face of nations reeling from conflict, disaster, and dislocations, we hope to be better equipped in order to participate in the healing of the nations.

Why do the nations conspire, and the peoples plot in vain?

... Blessed are all

who take refuge in him. $^{3}$

\section{References}

1. United Nations High Commission for Refugees. Statistical Yearbooks. Figures at a glance. [Internet] Available from: http://www.unhcr.org/figures-at-aglance.html

2. Office of Religious Life. Princeton University. Seeking Refuge: Faith-Based Approaches to Forced Migration. 3-4 March, 2017. Available from: https://religiouslife.princeton.edu/programsevents/interfaith/poverty-peacemaking/pdfs

3. Psalm 2. Holy Bible. New International Version.

www.cjgh.org

Sept 2018. Christian Journal for Global Health, 5(2):1-2. 